\title{
There Is Nothing that Interpretation Just Is
}

\section{Citation}

Cass R. Sunstein, There Is Nothing that Interpretation Just Is (Aug. 29, 2014).

\section{Permanent link}

http://nrs.harvard.edu/urn-3:HUL.InstRepos:16145974

\section{Terms of Use}

This article was downloaded from Harvard University's DASH repository, and is made available under the terms and conditions applicable to Open Access Policy Articles, as set forth at http:// nrs.harvard.edu/urn-3:HUL.InstRepos:dash.current.terms-of-use\#OAP

\section{Share Your Story}

The Harvard community has made this article openly available.

Please share how this access benefits you. Submit a story.

Accessibility 


\title{
Very preliminary draft $8 / 30 / 2014$ All rights reserved
}

\section{There Is Nothing that Interpretation Just Is}

\author{
Cass R. Sunstein
}

\begin{abstract}
Some people believe that the very idea of interpretation requires judges to adopt a particular method for interpreting the Constitution. The problem with this view is that in constitutional law, the general idea of interpretation is compatible with a range of different approaches, and among them, none is mandatory, in the sense of having some unique or privileged connection with the general idea. Any particular approach must be defended on the ground that it would make our constitutional order better rather than worse. No one should doubt that there are legitimate questions about the institutional capacities of judges, and about the virtues and vices of a deferential role on their part; the answers to those questions can motivate a view about constitutional interpretation. But they do not depend on an understanding of what interpretation necessarily requires.
\end{abstract}

\section{The Thesis}

Many people believe that the Constitution must be interpreted in their preferred way. They insist that the very idea of interpretation requires judges to adopt their own method of construing the founding document. ${ }^{1}$

The problem with this view is that in the legal context, there is nothing that interpretation "just is." 2 Among the reasonable alternatives, no approach to constitutional interpretation is mandatory. Any approach must be defended on normative grounds -- not asserted as part of what interpretation requires by its nature. Whatever their preferred

\footnotetext{
* Robert Walmsley University Professor, Harvard University. I am grateful to Larry Alexander, Eric Posner, Frederick Schauer, Lawrence Solum David Strauss, and Mark Tushnet for invaluable comments on a previous draft. Special thanks to Solum for particularly detailed and illuminating suggestions, from which I have learned a great deal. This essay expands on the discussion in chapter 1 of Cass R. Sunstein, A Constitution of Many Minds (2011), but there are significant changes in the central argument. ${ }^{1}$ See, e.g., Larry Alexander, Simple-Minded Originalism (2008), available at http://papers.ssrn.com/sol3/papers.cfm?abstract id=1235722; Walter Benn Michaels, A Defense of Old Originalism, 31 Western New England Law Review 21, 21 (2009).

2 The interpretation-construction distinction complicates this basic claim; for discussion, see below.
} 
approach, both judges and lawyers must rely on normative judgments of their own. ${ }^{3}$ Nonetheless, they sometimes claim that their own approach is necessary, in the sense that they have no choice but to adopt it, if they are to engage in interpretation at all. That claim is a recipe for confusion.

It is true that some imaginable practices cannot count as interpretation at all. If judges do not show fidelity to authoritative texts, they cannot claim to be interpreting them. But without transgressing the legitimate boundaries of interpretation, judges can show fidelity to texts in a variety of ways. Within those boundaries, the choice among possible approaches depends on the claim that it makes our constitutional system better rather than worse. Importantly, this conclusion does not, by itself, rule out any of the established approaches, including originalism in its various forms, ${ }^{4}$ democracyreinforcement, "moral readings," ${ }^{5}$ minimalism, ${ }^{7}$ or broad deference to political processes. ${ }^{8}$ But it does establish the terrain on which the debates ${ }^{9}$ must be undertaken. ${ }^{10}$

\section{On the Very Idea of Interpretation}

\section{A. Original Intentions}

Consider one view: In interpreting the meaning of words, we ask about authorial intentions. (I use the term "author" to include speakers as well as writers.) That is what it means to interpret words.

${ }^{3}$ This is so even if those implicit judgments direct them to defer to, or to accept, the normative judgments of other people. See James Bradley Thayer, The Origin and Scope of the American Doctrine of Constitutional Law, 7 HARV. L. REV. 129 (1893).

${ }^{4}$ See Antonin Scalia, Originalism: The Lesser Evil, 57 U Cin L Rev 849 (1989).

${ }^{5}$ John Hart Ely, Democracy and Distrust (1983).

${ }^{6}$ Ronald Dworkin, Freedom's Law: The Moral Reading of the American Constitution (1997).

${ }^{7}$ Cass R. Sunstein, One Case At A Time (2001).

${ }^{8}$ See J. Harvie Wilkinson, Cosmic Constitutional Theory (2012); Adrian Vermeule, Judging under Uncertainty (2006). See also Jeremy Waldron, The Core of the Case Against Judicial Review, 115 Yale LJ 1346 (2006) (making a contingent argument against judicial review, in part on consequentialist grounds).

${ }^{9}$ The valuable discussion in Lawrence B. Solum, The Positive Foundations of

Formalism: False Necessity and American Legal Realism, 127 Harv L Rev 2464 (2014), can be understood to sketch a consequence-focused argument for originalism and plain meaning approaches to legal texts. See also John O. McGinnis and Michael B.

Rappaport, Originalism and the Good Constitution (2013).

${ }^{10}$ My focus throughout is on constitutional interpretation, but it should be plain that the same analysis applies to statutory interpretation as well. For instructive and sympathetic discussions of textualism, see John Manning, Second-Generation Textualism, 98 Cal. L. Rev. 1287 (2010; John Manning, Textualism and Legislative Intent, 91 Va L Rev 419 (2006). For a prominent rejection of textualism, see Stephen Breyer, Active Liberty (2009). 
It is true that in ordinary life, we tend to interpret words in this way. ${ }^{11}$ If a friend asks you to meet her at "my favorite restaurant," you will probably ask what, exactly, she had in mind. You will not ask which restaurant you like best, or which restaurant is preferred by your favorite restaurant critic. It might even be consistent with ordinary usage to say that in ordinary conversational settings, interpretation of people's words amounts to an effort to elicit their intentions. ${ }^{12}$ Of course, this conclusion invites attention to context and purposes, not just words. If a friend makes some kind of linguistic error, we would not want to hold her to those words. But when we depart from her words, it is because we are trying to figure out what she had in mind.

Some people think that legal interpretation is not fundamentally different. In their view, a form of originalism, based on the idea of authorial intention, is built into the concept of interpretation. For example, Larry Alexander writes that "given what we accept as legally authoritative, the proper way to interpret the Constitution . . . is to seek its authors' intended meanings - the same thing we do when we read a letter from Mom, a shopping list from our spouse, or instructions for how to assemble a child's toy made in China." 13 Walter Benn Michaels goes even further: "In fact, however, you can't do textual interpretation without some appeal to authorial intention and, perhaps more controversially, you can't (coherently and nonarbitrarily) think of yourself as still doing textual interpretation as soon as you appeal to something beyond authorial intention-for example, the original public meaning or evolving principles of justice."14

It is true that we could define legal interpretation in this way. But if Alexander and Michaels are using "interpretation" in the standard legal sense, the definition would be a stipulation, ${ }^{15}$ and it would not be based on the necessary meaning of the term. Let us suppose that in ordinary conversation, most people understand the idea of interpretation to involve a search for authorial intentions. Even in that context, such an understanding is not mandatory; we could imagine the view that interpretation involves a search for public meaning, rather than authorial intentions. ${ }^{16}$ But it is certainly sensible to say that in

${ }^{11}$ H.P. Grice, Studies In the Way of Words (1989).

12 See id.

${ }^{13}$ Larry Alexander, Simple-Minded Originalism (2008), available at http://papers.ssrn.com/sol3/papers.cfm?abstract_id=1235722

${ }^{14}$ See Walter Benn Michaels, A Defense of Old Originalism, 31 Western New England Law Review 21, 21 (2009). For an analogous argument, see Steven Smith, Law's Quandary (2007); for an analogous argument with a focus on meaning rather than intentions, see Gary Lawson, On Reading Recipes . . . and Constitutions, 85 Geo LJ 1823 (1997). For an instructive discussion, also with an emphasis on meaning, see Lawrence Solum, Semantic Originalism (2008), available at http://papers.ssrn.com/sol3/papers.cfm?abstract_id=1120244

15 Alexander, supra note, does offer a nonstipulative argument, taken up below.

${ }^{16}$ It is true, however, that such an approach would make conversation work less well, at least if it is too literal. Some science fiction characters apply this method to unfortunate 
conversation, we ask about intentions. If this is indeed sensible, it is for a pragmatic reason; the goal of the particular communication will not be met if we do not. When a friend asks me to meet her, or to do something for her, I am likely to ask about her intentions, because I want to meet her or to do as she would like. If my friend says that we should "meet at the best restaurant in town," I will likely ask what she meant by those words. It is imaginable, of course, that she wants me to do a little work and to see what the restaurant critics like best - but if so, I am still trying to follow her subjective intentions. If interpretation entails that practice, it is because in the relevant context, that is the best way to understand the term.

The same things might be said about communication within some hierarchical organization. If a supervisor tells an employer what to do, it is right to think that in ordinary circumstances, the employee ought to ask: "What, exactly, did my supervisor mean by that?" (The qualification "in ordinary circumstances" is necessary because even subordinates sometimes ask about something other than speaker's intentions; everything depends on the role of the subordinate, some of whom might have a different or less deferential role.) The employee asks this question, if he does, for pragmatic reasons. Employees should generally follow the instructions of their supervisors, and the practice of following instructions, in hierarchical organizations, usually calls for close attention to the supervisors' subjective intentions. It is plausible to say that in some contexts, interpretation of the instructions of a supervisor "just is" an effort to elicit and follow subjective intentions - not in the sense that this understanding of interpretation is inevitable or strictly mandatory, but in the sense that it captures how most people use the term in such contexts. If that is true, it is because this understanding of interpretation makes the supervisor-employee relationship work best.

A possible response would be that at least in many contexts, it is not even possible to interpret people's words without making some kind of judgment about the author's intentions. On this view, the idea of meaning depends on some such judgment, and it is incoherent without it. In the legal context, this claim is plainly false, for reasons that are elaborated below. ${ }^{17}$

\section{B. Original Meaning}

One conception of interpretation involves a search for speaker's intentions, and in ordinary life, that is the most common conception. But it is easy to think of cases in

effect; consider Data in the television series Star Trek: The Next Generation. "Nerd humor" often consists of the use of public meaning, rather than intentions.

${ }^{17}$ There is a question whether it is false even in ordinary communications. Suppose that you look up at a pattern of clouds in the sky. To your surprise, the pattern spells out the word "God." Whether or not you have faith, you will have no hesitation identifying that word. Conventions about language may be sufficient for the identification, suggesting the possibility that we can understand the meanings of words by reference to those conventions, without necessarily making judgments about author's intentions. This example is contested in Steven Smith's, Law's Quandary (2004). 
which interpretation does not operate by reference to such intentions. In fact some of the most committed originalists, including Justice Scalia himself, believe that what matters is the original public meaning of the document, not intentions at all. ${ }^{18}$ In Heller, for example, Justice Scalia wrote that in "interpreting [the Second Amendment], we are guided by the principle that ' $[\mathrm{t}]$ he Constitution was written to be understood by the voters; its words and phrases were used in their normal and ordinary as distinguished from technical meaning." 19 In his view, "Normal meaning may of course include an idiomatic meaning, but it excludes secret or technical meanings that would not have been known to ordinary citizens in the founding generation." 20

Originalists themselves argue fiercely about whether the original meaning, or instead the original intentions, should be taken as authoritative ${ }^{21}-$ a point that suggests that interpretation, to qualify as such, need not be focused on intentions. Those who focus on original public meaning argue that meaning is objective, not subjective. In their view, what matters is the standard understanding among the Constitution's ratifiers, not what the authors "intended." After all, the ratifiers ("We the People"), and not the authors, turned the Constitution into law. Rejecting subjective intentions, Justice Holmes wrote, "We do not inquire what the legislature meant; we ask only what the statutes mean.",22

${ }^{18}$ See District of Columbia v. Heller, 554 US 570 (2008). Grice similarly distinguishes between "speaker's meaning" and "sentence meaning." See H. P. Grice, Utterer's Meaning, Sentence-Meaning, and Word Meaning, 4 Found. Language 225, 225 (1968). ${ }^{19} \mathrm{Id}$.

${ }^{20} \mathrm{Id}$.

${ }^{21}$ See Michaels, supra note; Lawson, supra note; Lawrence Solum, Semantic Originalism (2008), available at http://papers.ssrn.com/sol3/papers.cfm?abstract id $=1120244$

${ }^{22}$ Oliver Wendell Holmes, The Theory of Legal Interpretation, 12 Harv L. Rev. 417 (1899). See Lawrence Solum, Semantic Originalism 5 (2008), available at http://papers.ssrn.com/sol3/papers.cfm?abstract_id=1120244: “The argument for clause meaning will be elaborated at length, but the intuitive idea is simple. The constitution was drafted and ratified by a multitude: many different individuals at different times and places. The intentional mental states of the multitude with respect to a given constitutional provision (their purposes, hopes, fears, expectations, and so forth) will themselves be multitudinous and inaccessible. Multitudinous, because different framers and ratifiers had different intentions, with the consequence that intentions alone cannot fix consistent (noncontradictory and not radically ambiguous) semantic content. Inaccessible, because those who were expected to engage in constitutional practice (the judges, officials, and citizens of the United States of American for an indefinite future) would have found the multitudinous intentions epistemically inaccessible." Solum adds: "The possibility of constitutional communication was created by the fact that the framers and ratifiers could rely on the accessibility of the public meaning (or conventional semantic meaning) of the words, phrases, and clauses that constitute the Constitution. Not only can such public meanings enable constitutional communication at the time a given constitutional provisions is drafted, approved, and first implemented, such meanings can also become stable over time or be recovered if they are lost. In other words, under normal conditions successful constitutional communication requires reliance by the 
Of course those who insist on adherence to the original public meaning count as originalists $^{23}$-- but they do not rely on subjective intentions. ${ }^{24}$ At this point, my goal is not to take a stand on which form of originalism is best or most coherent, or to suggest that the original meaning must be taken as fixed and binding. ${ }^{25}$ (The very idea has more than one meaning. ${ }^{26}$ ) It is only to insist that a prominent understanding of originalism -as involving public meaning rather than intentions -- is enough to demonstrate that attention to subjective intentions is not built into the very idea of interpretation. ${ }^{27}$

\section{Consequences}

Is it plausible to say that interpretation necessarily entails a search for the original public meaning? Not at all. ${ }^{28}$ Alexander is right to suggest that interpretation often involves an inquiry into intentions rather than public meaning. (Recall that if your friend says, "let's go to the best movie now playing," you ask what she has in mind, not what is generally recognized as best, unless that is what she has in mind.) We could also imagine a form of textualism that inquiries about contemporary meaning -- thus calling for adherence to the current, rather than the historical, meaning of the constitutional text. To their credit, many of those who insist on fidelity to the original meaning do not insist that their own view is compelled by the very idea of interpretation. Instead they suggest that their own approach would lead to better consequences. ${ }^{29}$

drafters, ratifiers, and interpreters on the original public meaning of the words and phrases." Id.

${ }^{23}$ For a valuable discussion, see Lawrence Solum, Semantic Originalism (2008), available at http://papers.ssrn.com/sol3/papers.cfm?abstract_id=1120244

${ }^{24}$ See Antonin Scalia, Book Review, 55 Catholic Univ L. Rev. 687 (2006), and in particular this suggestion, as against an advocate of authorial intention: "Smith confuses, it seems to me, the question whether words convey a concept from one intelligent mind to another (communication) with the question whether words produce a concept in the person who reads or hears them (meaning). The bridegroom who says 'I do,' intending by that expression to mean 'I do not,' has not succeeded in communicating his intent; but what he has said unquestionably means that he consents to marriage."

${ }^{25}$ In a detailed and instructive discussion, Lawrence Solum urges, "The core of the affirmative case for the Fixation Thesis is rooted in common sense intuitions about the meaning of old texts of all kinds." Lawrence Solum, The Fixation Thesis 22 (unpublished manuscript, 2014). One question is the weight to be given to those "common sense intuitions." In my view, the answer is normative; it cannot emerge simply by recognizing what those intuitions are.

${ }^{26}$ See Jack Balkin, Living Originalism (2012).

${ }^{27}$ See Lawrence Solum, Constitutional Texting, 44 San Diego L Rev 123 (2007), and in particular Solum's suggestion: "Constitutional text messages will work best if they are constructed from widely shared public meanings" (emphasis added).

${ }^{28}$ I am putting to one side the interpretation-construction discussion, discussed below.

${ }^{29}$ See Scalia, supra note; John O. McGinnis and Michael B. Rappaport, Originalism and the Good Constitution (2013). 
For example, Justice Scalia stresses the risks associated with judicial discretion, and he contends that if judges adhere to original meaning, those risks will be diminished, because judges will be constrained. ${ }^{30}$ Some originalists focus on the goal of democratic self-government, and they argue that if judges respect the original meaning, they will promote that goal. Consider the illuminating suggestion by Randy Barnett: "Given a sufficiently good constitutional text, originalists maintain that better results will be reached overall if government officials -- including judges -- must stick to the original meaning rather than empowering them to trump that meaning with one that they prefer." ${ }^{31}$ This is an explicit argument that the case for originalism depends on what will produce "better results" overall. ${ }^{32}$

Of special importance here is Barnett's emphasis on the need for a "sufficiently good constitutional text," understood in light of the original meaning. Suppose that the constitutional text, taken only as such, is good, or good enough. But suppose that it is a great deal worse if it is understood in light of its original meaning. Imagine, for example, that it is hopelessly undemocratic, or that it entrenches racial injustice. If so, the argument for sticking with the original meaning would be weakened. In fact this is not an implausible account of the American Constitution. The text itself contains broadly appealing phrases, protecting "the freedom of speech" and guaranteeing "due process of law" and "the equal protection of the laws," and vesting executive power in "a president of the United States." There is a good argument that if these words were construed in accordance with their original meaning, understood in terms of its expected applications, ${ }^{33}$ our constitutional order would be far worse than it is today. ${ }^{34}$

True, we should agree that judges should be faithful to the text itself, even if the text were not as good as it is. If judges were not faithful to the text, it is fair to say that they would not be engaged in interpretation at all. ${ }^{35}$ If judges disregard authoritative texts, they cannot claim to be interpreting them. In that sense, the idea of interpretation does impose constraints on what judges may do. Moreover, legal systems do much better - and even count as legal systems ${ }^{36}$ - if judges are faithful to authoritative texts. If they

\footnotetext{
${ }^{30}$ Scalia, supra note.

${ }^{31}$ Available at http://legalaffairs.org/webexclusive/debateclub_cie0505.msp.

${ }^{32}$ See also Lawson, supra note: "It is highly improbable that any plausible argument for the Constitution's authority can be made that does not, at least to some extent, depend on the Constitution's substance."

${ }^{33}$ I am bracketing the question whether that is the right way to understand them. The only suggestion is that there is a strong argument against originalism if, understood in a certain way, it makes our constitutional system worse. It remains possible that some understandings of originalism would not have that effect.

${ }^{34}$ See David A. Strauss, The Living Constitution (2011).

${ }^{35}$ Lawrence Solum, The Interpretation-Construction Distinction, 27 Constitutional Commentary 95 (2010).

${ }^{36}$ Cf. Lon Fuller, The Morality of Law (1964).
} 
do not, the rule of law is itself in jeopardy, ${ }^{37}$ because judges would appear to be empowered to do whatever they want. In that sense, there is an excellent consequentialist argument in favor of taking constitutional texts as binding. ${ }^{38}$ But under the assumptions I have given, why should judges stick not merely with the text but also with its original meaning? If the consequences of sticking with it would be terrible, and if those consequences could be avoided with another approach, shouldn't judges consider that other approach?

These questions are not meant to be rhetorical; they suggest only that various approaches to interpretation are on the table. Many originalists find it both appropriate and necessary to argue that the consequences of their approach would not be terrible. ${ }^{39}$ With Barnett, they urge that those consequences would be good. ${ }^{40}$ They contend that their approach fits with a great deal of existing judicial doctrine, or at least with those aspects of it that seem least dispensable. ${ }^{41}$ Few contemporary originalists are willing to concede that under their approach, racial segregation is constitutionally acceptable -- even though nothing in the original meaning bans segregation by the national government, and even though it is not at all easy to show that the Constitution bans segregation at the state level. Few contemporary originalists agree that their approach would allow the national government to prohibit women from working for the federal civil service, or would freely allow states to discriminate against women.

On the contrary, originalists tend either to say little about the difficulty in squaring their approach with foundational commitments of the contemporary

${ }^{37}$ For the best discussion, see Joseph Raz, The Rule of Law and its Virtue, in The Authority of Law: Essays on Law and Morality (1979).

${ }^{38}$ This conclusion is not meant to address the question whether and when it is legitimate to construe the text in a way that does not quite fit its words, as in the claim that the first amendment ("Congress shall make no law abridging") applies to all of the national government, and not merely Congress. Nor am I suggesting that consequentialism is the only way to choose among possible approaches to interpretation. See note 32 infra.

${ }^{39}$ We could imagine an argument that does not make a particular claim about what interpretation is, and that does not rest on consequences, but that invokes moral or political legitimacy. Such a claim might point in originalist or nonoriginalist directions. On the latter, see Ronald Dworkin, Law's Empire (1985). I do not believe that arguments of this kind are promising, but I will simply bracket them here; they should be taken to be claims about what makes our constitutional order best, in the relevant sense.

${ }^{40}$ See the subtle argument in Lawrence B. Solum, The Positive Foundations of Formalism: False Necessity and American Legal Realism, 127 Harv L Rev 2464 (2014), which can be read to suggest a consequentialist argument in favor of originalism, stressing the virtues of stability and predictability.

${ }^{41}$ See Michael McConnell, Originalism and the Desegregation Decisions, $81 \mathrm{Va}$ L Rev 233 (1995); Steven Calabresi and Andrea Matthews, Originalism and Loving v. Virginia (2012), available at http://scholarlycommons.law.northwestern.edu/cgi/viewcontent.cgi?article=1205\&contex $\mathrm{t}=$ facultyworkingpapers. 
constitutional order, or to insist that the difficulty is not so severe, because originalism already embodies those commitments. ${ }^{42}$ Some originalists work extremely hard to try to demonstrate that point. ${ }^{43}$ They are right to do so, because the argument for their approach depends on that work. Whether or not that argument is convincing, what is noteworthy that many of those who stress original meaning find it necessary to stress these points about consequences. They do not rest content with, or even make, the claim that their approach is built into the very idea of interpretation. The same is true for those who invoke claims about moral or political legitimacy. ${ }^{44}$

Indeed, some originalists, notably Jack Balkin, insist that certain provisions of of the Constitution are written in general and abstract terms, which allows accommodation of evolving understandings. ${ }^{45}$ Some people who hold this view contend that the original understanding was that the Constitution creates broad principles whose concrete meaning would not be frozen in time. ${ }^{46}$ If their claim is about the intended meaning, or about the public meaning, it is not clear that they are right; the evidence is ambiguous here. ${ }^{47} \mathrm{But}$ if they are, the line between originalism and other approaches starts to dissolve,${ }^{48}$ because interpretation of abstractions - what counts as "equal protection" or "the freedom of speech" - squarely invites the exercise of discretion on the part of the judges. And if Balkin's view of interpretation is correct, my main conclusion holds: It is not because of anything intrinsic to the idea, but because its adoption would make our constitutional system better rather than worse.

\section{Fit and Justification}

I have emphasized the concept of interpretation does impose constraints. Some approaches cannot qualify as interpretation at all. Even if it would be good, pragmatically speaking, to substitute the best imaginable constitution for our own constitution, the substitution cannot count as interpretation. But the concept of interpretation does not compel any form of originalism.

Let us now turn to nonoriginalist approaches. Suppose a judge thinks that where the Constitution is vague or open-textured, he should interpret it to make the democratic process work as well as it possibly can - an idea that John Hart Ely ${ }^{49}$ and Justice Breyer ${ }^{50}$

${ }^{42}$ See note supra.

${ }^{43} \mathrm{Id}$.

${ }^{44}$ See note supra.

${ }^{45}$ See Jack Balkin, Living Originalism (2012).

${ }^{46}$ See H. Jefferson Powell, The Original Understanding of Original Intent, 98 Harvard L. Rev. 885 (1985).

${ }^{47}$ See id.; Solum, The Fixation Thesis (unpublished manuscript 2014); cf. Philip Hamburger, The Constitution's Accommodation of Social Change, 88 Mich L Rev 239 (1989).

${ }^{48}$ Balkin, supra note.

${ }^{49}$ Ely, supra note.

${ }^{50}$ See Stephen Breyer, Active Liberty (2009). 
have vigorously championed. Is that approach ruled off-limits by the very idea of interpretation? It is hard to see why. Justice Breyer has argued that a democracyprotective approach, honoring "active liberty," fits with the text and purposes of the document even if it does not fit with the original meaning, narrowly conceived. ${ }^{51}$ (Recall that some originalists think that the Constitution was deliberately written in broad terms whose meaning was meant to evolve over time.) Breyer's approach must be evaluated on its merits; it cannot be ruled off the table. To his credit, Breyer is candid about this point, and contends that the consequences of his preferred approach would be good. ${ }^{52}$

The same is true for Dworkin's preferred view, which is that the Constitution should be taken to include abstractions that invite moral reasoning from judges, and that judges must give those generalities the best moral readings that they can. ${ }^{53}$ Indeed, both the Lochner Court ${ }^{54}$ and the Warren Court ${ }^{55}$ approached the Constitution in this way, and many people, on both the right and the left, think the Court should resume something like this approach today. ${ }^{56}$ Whether or not it is the right approach, it would certainly count as interpretation within permissible linguistic understandings of the term.

Dworkin has argued that legal interpretation involves two obligations ${ }^{57}$ The first obligation is one of "fit"; an interpreter cannot simply ignore the materials that are being interpreted. The second is one of "justification." What Dworkin means is that within the constraints of fit, an interpret must justify the existing legal materials ${ }^{58}$ in the sense of making them the best that they can be. To explain this approach, Dworkin offers the arresting analogy of a chain novel. ${ }^{59}$ Suppose that you are the fifth writer in a chain, and that your task is to write the fifth chapter. Four writers have written four chapters before you. In writing the fifth chapter, you must write the novel that others have started, and not another. You cannot make up a whole new novel. Nor can you depart from what has come before, in the sense of producing a narrative that ignores it or makes it unintelligible or random. But you might well think that you have an obligation to make the novel good rather than terrible, and your authorship of the next chapter will be undertaken with that obligation in mind.

${ }^{51}$ See id.

${ }^{52}$ See id.

${ }^{53}$ See Dworkin, supra note.

${ }^{54}$ See Lochner v. New York, 198 US 45 (1905).

${ }^{55}$ See, e.g., Brown v. Bd of Educ., 347 US 483 (1954); Reynolds v. Simms, 377 US 533 (1964).

${ }^{56}$ Richard A. Epstein, The Classical Constitution (2014), seems to me in this vein.

${ }^{57}$ Ronald Dworkin, Law's Empire (1985).

${ }^{58}$ I am bracketing for the moment the question whether those materials are limited to authoritative texts or whether they include (for example) previous judicial interpretations.

${ }^{59}$ See Ronald Dworkin, Law's Empire (1985). Of course there are diverse conceptions of what a novel is - of how it might be written and of how the various parts fit together.

Dworkin is assuming a conventional conception, associated with nineteenth-century novels. 
Dworkin is right to observe that at least in a case system, judicial judgments often seem a lot like that. It is generally agreed that in the American constitutional system, judges who interprets the Constitution owe a duty of fidelity to what has come before (subject to the relevant theory of mistake). ${ }^{60}$ But they also have a degree of discretion. They can turn the tale in one direction or another. If, for example, the question is whether the Constitution requires states to recognize same-sex marriage, they must ask: What approach makes the best sense out of the existing materials? Of course it is true that an emphasis on fit and justification leaves many questions open. A recurring question is the relationship among the caselaw, social practices, and the original understanding of the text; what does the obligation of fit mean when these point in different directions ${ }^{61}$ ? Different answers to that question are admissible within the general concept of interpretation. Democracy-reinforcement is one attempt to answer; so is originalism, focused as it is on the authoritative text and original understandings.

On the basis of Dworkin's argument, we might be tempted to think (as Dworkin does) that there is one thing that legal interpretation just is: an attempt to ensure both fit and justification. And it is true that originalists and moral readers, minimalists and democracy-reinforcers, those who insist on a presumption of constitutionality - all of these, and more, can accept the view that both fit and justification matter. But the temptation should be resisted. While Dworkin's approach is one conception of interpretation, it is not the only one. If we believe that interpretation involves the search for authorial intentions, we will not much care about justification. We will attempt to identify a fact: What did the author(s) intend? It is true that the answer to that question might be difficult to find, and it is also true that there may be no answer to that question. But if so, we may have exhausted the act of interpretation. (Something similar can be said about those who emphasize the original public meaning.) At least that is one view (again, not the only one) of what interpretation is.

\section{E. Interpretation and Construction}

With a point of this kind in mind, some people have insisted on the importance of making a distinction between "interpretation" and "construction." " In an especially clear and illuminating discussion, Lawrence Solum suggests that interpretation attempts to discover the linguistic or semantic meaning of a legal text, whereas construction gives legal effect to that meaning. ${ }^{63}$ The first amendment, for example, has a linguistic meaning ("no law abridging"), and no one can argue that the linguistic meaning is identical to various first amendment doctrines (the public forum doctrine, the lower level of protection accorded to commercial advertising, the exclusion of bribery, the distinction

\footnotetext{
${ }^{60}$ I mean to bracket the question of how much weight judges should accord to precedents.

${ }^{61}$ See Canning v. NLRB, US (2014), where the justices divided on answering that question.

${ }^{62}$ See Keith Whittington, Constitutional Construction (1999).

${ }^{63}$ See Lawrence Solum, The Interpretation-Construction Distinction, 27 Constitutional Commentary 95 (2010). As Solum emphasizes, the distinction has a long history and has been understood in several different ways.
} 
between content-based and content-neutral restrictions). Solum urges that interpretation "is guided by linguistic facts - facts about patterns of usage," ${ }^{64}$ and is in that sense valuefree or only "thinly normative," 65 in the sense that our normative views about what the law should be do not determine whether an interpretation is correct.

By contrast, "theories of construction are ultimately normative," in the sense that a judgment on behalf of one construction rather than another turns on "premises that go beyond linguistic facts." In Solum's terminology, an approach that favors deference to the political process is a theory of construction; it is unquestionably normative, but it does not allow judges to enlist their own moral or political beliefs in particular cases. When linguistic meaning of a text is vague (as it seems for many constitutional provisions), then the fact that judges are involved in construction, rather than interpretation, seems obvious. On Solum's view, interpretation gives rise to a "construction zone." ${ }^{67}$ For judges who find themselves in that zone, there are many ways to proceed; deference to the political process is merely one.

If we accept this distinction, then we might say that there is nothing that construction just is, because construction cannot occur without some kind of normative argument, and because several (or many) normative arguments are consistent with the basic idea of construction. But on this view, there is something that interpretation just is, which is the elicitation of linguistic meaning. For this reason, some version of textualism - in Solum's own account, one that is rooted in the original public meaning ${ }^{68}$-- is a necessary foundation for interpretation. The word "speech," for example, cannot mean "Mars," or "President," or "horse," or "flood," or "ketchup," and the words "due process" cannot mean "with pancakes" or "American slavery" or "long-burning candle." In the eighteenth century, the word "goal" meant "jail," and if we read an eighteenth-century legal text using that word, we might well insist on the original public meaning to interpret it.

As Solum acknowledges, however, there are different approaches to the identification of linguistic meaning. Original intention and original meaning are two, and it would also be possible (whether or not reasonable) to identify such meaning by pointing to contemporary understandings. In the case of an eighteenth-century text with the word "goal," we would be drawn to some form of the originalism. (The same is true of the words "domestic violence" in the Constitution. ${ }^{69}$ ) Interpretation, understood as the search for linguistic meaning, can be treated as an important or even as the critical part of "fit" - and it is distinctive, because it fastens on the obligation to attend to the semantic meaning of authoritative texts.

\footnotetext{
${ }^{64}$ Id. at 104.

${ }^{65} \mathrm{Id}$.

${ }^{66} \mathrm{Id}$.

${ }^{67} \mathrm{Id}$.

${ }^{68}$ See Solum, Semantic Originalism, supra note.

${ }^{69}$ See id.
} 
If the distinction between interpretation and construction is understood in these terms, it is illuminating, not least because it helps to explain the potential legitimacy of a wide range of conceptions of what would (in this light) be characterized as construction. Moreover, it is true that any theory of interpretation has to be textualist - not in the sense that it must always "follow" the text, or may never depart from its ordinary meaning, but in the sense that it must always make the text the foundation for interpretation. And if interpretation is understood narrowly, to mean the elicitation of linguistic meaning, then everyone should agree that courts must engage in it, and that it rules many approaches out of bounds, not as illegitimate, but as not involving interpretation at all. For my purposes here, however, the central problems are that more than one approach can plausibly be treated as interpretive, and that in many cases, the idea of construction is doing crucial work. Indeed, we can understand those who deploy the interpretation/construction distinction as specifying a particular conception of interpretation - a conception that is reasonable and useful but by no means universally shared, and that diverges sharply from (for example) the conception used by Dworkin. In other words, Solum offers a narrow and linguistically plausible conception of what counts as interpretation, but in law, the idea of interpretation is often used to include what he characterizes as construction (as Solum acknowledges).

In fact Solum goes further. He argues that "as a matter of fact, the meaning of a given constitutional provision is fixed at the time of origin by its original public meaning," and also that "as a matter of fact, the semantic content makes some contribution to American law." In his view, "these factual claims are not based on arguments of political morality," but instead rest on an understanding of how "communication through language works." "70 Solum seeks to "derive conclusions about constitutional meaning from nonnormative premises - that is, on the basis of premises that are not ethic or moral in nature."71 Solum's defense of this position is subtle and complex, but it is not clear that an understanding of "how communication through language works" can bear the relevant weight. Solum enlists an analogy: If we read a letter from centuries ago, and if it contains the word "deer," we will interpret it by asking about the meaning of that word when the letter was written, not by consulting modern dictionaries. (Recall the eighteenth-century meaning of the word "goal.") That is true, but is the constitutional setting analogous? Consider the view that judges should decide, as a matter of principle, whether current practices do deny people "equal protection of the laws," or violate "the freedom of speech," rather than asking about the original meaning of those words. Whether that view is right or wrong is a normative question. It cannot be settled by an understanding of how communication through language works. Philosophical work on that topic does not resolve the question of the appropriate judicial role undertaken under the capacious rubric of "interpretation."

\section{Decision Costs and Error Costs}

${ }^{70}$ Solum, Semantic Originalism, supra note, at 8 .

${ }^{71}$ Id. at 10. 
Among the permissible alternatives, identification of the proper approach to constitutional interpretation requires attention whether it would make our constitutional order better or worse. To be a bit more systematic: An approach to the Constitution might impose two kinds of costs. It might impose decision costs, by complicating people's judgments, and it might impose error costs, by producing bad outcomes.

Without making the ludicrous claim that these ideas should be understood in purely economic terms, we can insist that judges should consider the decisional burdens imposed by one or another approach to the founding document. Those burdens, or costs, might be faced by judges or by others, including legislators, members of the executive branch, and citizens themselves, who must pay the cost of uncertainty. If courts declared that they would upheld any legislation unless the constitutional violation were clear, ${ }^{72}$ they would certainly lower low decision costs, simply because almost all legislation would be immediately upheld. For judges, application of a deferential approach is generally straightforward. Originalists believe that their approach also lowers decision costs, and in particular that it promotes the rule of law, by increasing clarity and predictability. ${ }^{73}$ And to the extent that minimalism focuses judges narrowly on particular problems, it too imposes modest decisional burdens - at least in specific cases. ${ }^{74}$

But it is also important to consider the number and the magnitude of errors. There would be serious reason to question any approach to the Constitution that would declare race and sex discrimination to be unobjectionable, or that would raise serious constitutional doubts about practices that the President and Congress have accepted for many decades. If an approach would greatly unsettle current institutional practices, there is reason to question it for that reason alone. ${ }^{75}$ If an approach would badly compromise democratic self-government, it would be objectionable for that reason, though the intensity of the objection depends on how we specify the nature and limits of that ideal. ${ }^{76}$ And if an approach would eliminate or undermine rights that Americans enjoy, and deserve to enjoy, then the approach is questionable on that very ground.

True, reasonable people disagree about whether certain outcomes count as errors at all. Judges might agree that the choice among interpretive approaches depends on what approach makes our constitutional order best, but sharply disagree about how to answer that question. In my view, a disagreement of this kind helps to separate people who are

\footnotetext{
${ }^{72}$ Se Wilkinson, supra note.

${ }^{73}$ See Scalia, supra note. For a contrary view, finding that as an empirical matter, political preferences play a major role in purportedly originalist decisions, see Frank Cross, The Failed Promise of Originalism (2012).

${ }^{74}$ One problem with minimalism is that it "exports" costs to subsequent decisionmakers. See Scalia, supra note.

${ }^{75}$ Note that Justice Scalia describes himself as a "faint-hearted" originalist, because he is generally respectful of precedent. See Antonin Scalia, The Rule of Law As A Law of Rules, 56 U Chi L Rev 1175 (1989).

${ }^{76}$ For different views, see Epstein, supra note; Ely, supra note; Dworkin, supra note; Breyer, supra note.
} 
committed to different approaches to constitutional interpretation. ${ }^{77}$ Nearly everyone would agree that if an approach is inconsistent with Brown v. Bd. of Educ., or with Loving $v$. Virginia, it runs into problems for that reason. And nearly everyone would agree that if an approach would license judges to invalidate legislation whenever they liked, it would be unacceptable for that reason as well. But if one or another approach would mean that the Constitution protects no right of privacy, does that count against that approach, or in its favor? If an approach would reduce constitutional protection of rights, is that a terrible problem, or might it be not so bad in light of the possibility (likelihood?) that democratic process would respect and protect such rights on their own? We can easily imagine disputes about such questions. Notably, they would have a significant empirical dimension.

Often there is sufficient agreement to permit diverse people to engage with one another about appropriate approaches. But it must be emphasized that some arguments about the appropriate approach to interpretation are (implicitly) disputes about what kinds of results count as errors.

\section{Possible Worlds}

We can go further. No approach to constitutional law makes sense in every imaginable nation or in every possible world. ${ }^{78}$ The argument for any particular approach must depend, in large part, on a set of judgments about institutional capacities -- above all, about the strengths and weaknesses of legislatures and courts. We cannot assess decision costs and errors costs without making those judgments. If judges are excellent and error-free, their excellence bears on the choice of a theory of interpretation. If judges are likely to blunder, their fallibility bears on the choice of a theory of interpretation.

Consider this view, associated with James Bradley Thayer: Courts should uphold legislation unless it is plainly and unambiguously in violation of the Constitution. ${ }^{79}$ Few people now accept Thayer's position, which has found no support on the contemporary Supreme Court. Because the Constitution is frequently ambiguous, Thayer's approach

\footnotetext{
${ }^{77}$ There are also, of course, disagreements about the role of intuitions or judgments about the nature of communication, see Solum, Semantic Originalism, supra note, but for reason sketched above, I do not believe that any position on these issues can justify a unitary view about interpretation. See in particular the remarks above on the interpretation-construction distinction.

${ }^{78}$ Cf. Jeremy Waldron, The Core of the Case Against Judicial Review, 115 Yale LJ 1346, 1353 (2006): "My argument against judicial review is not unconditional but depends on certain institutional and political features of modern liberal democracies." See also id. at 1361: "In general, I am assuming that the democratic institutions are in reasonably good order. They may not be perfect and there are probably ongoing debates as to how they might be improved. I assume these debates are informed by a culture of democracy, valuing responsible deliberation and political equality. "

${ }^{79}$ See James Bradley Thayer, The Origin and Scope of the American Doctrine of Constitutional Law, 7 HARV. L. REV. 129 (1893). See also Vermeule, supra note.
} 
would require courts to uphold almost all legislation -- including school segregation in the District of Columbia, sex discrimination in federal employment, affirmative action, restrictions on abortion, mandatory school prayer, and much more. In these circumstances, it should be unsurprising that most judges assert their right to interpret the Constitution independently, refusing to accept the legislature's view merely because the document is ambiguous. In the last half-century, no member of the Court has been willing to endorse the proposition that legislation should be upheld unless the founding document is entirely clear.

But imagine a society in which democratic processes work exceedingly fairly and well, so that judicial intervention is almost never required from the standpoint of anything that really matters. ${ }^{80}$ In such a society, racial segregation does not occur. Political processes are fair, and political speech is never banned. The legitimate claims of religious minorities and property holders are respected. The systems of federalism and separation of powers are safeguarded, and precisely to the right extent, by democratic institutions.

Imagine too that in this society, judicial judgments are highly unreliable. From the standpoint of political morality, judges make systematic blunders when they attempt to give content to constitutional terms such as "equal protection of the laws" and "due process of law." Resolving constitutional questions without respecting the views of the legislature, courts would make society worse, because their understandings of rights and institutions are so bad. In such a society, a Thayerian approach to the Constitution would make a great deal of sense, and judges should be persuaded to adopt it. ${ }^{81}$ These are extreme assumptions, of course, but even if they are softened significantly, the argument for a Thayerian approach might be convincing, all things considered. ${ }^{82}$

${ }^{80}$ See Jeremy Waldron, The Core of the Case Against Judicial Review, 115 Yale LJ 1346, 1360 (2006): "We are to imagine a society with (1) democratic institutions in reasonably good working order, including a representative legislature elected on the basis of universal adult suffrage; (2) a set of judicial institutions, again in reasonably good order, set up on a nonrepresentative basis to hear individual lawsuits, settle disputes, and uphold the rule of law; (3) a commitment on the part of most members of the society and most of its officials to the idea of individual and minority rights; and (4) persisting, substantial, and good faith disagreement about rights (i.e., about what the commitment to rights actually amounts to and what its implications are) among the members of the society who are committed to the idea of rights."

${ }^{81}$ I put to one side the evident fact that Thayerism cannot be a complete account of constitutional interpretation. We might agree that courts should strike down statutes only when the violation of the Constitution is clear; but how do we know when the violation is clear? To work, Thayerism needs to be supplemented by some kind of account of constitutional meaning. On an extreme view, Thayerism would mean that courts should uphold legislation unless it is patently inconsistent with the Constitution on any account of how to ascertain its meaning.

${ }^{82}$ See Vermeule, supra note. 
Many people reject the idea of minimalism. ${ }^{83}$ But imagine a society in which the original public meaning of the Constitution is not so excellent, in the sense that it does not adequately protect rights, properly understood, and in the sense that it calls for institutional arrangements (say, between Congress and the President) that become obsolete over time, as new circumstances and fresh needs arise. Imagine that in this society, the democratic process is good but not great, in the sense that it sometimes produces or permits significant injustices. Suppose finally that in this society, judges will do poorly if they strike out on their own, or if they attempt to build doctrine on the basis of high-level theory, but very well if they build modestly and incrementally on their own precedents, following something like the common-law method. ${ }^{84}$ In such a society, a minimalist approach to the Constitution would have a great deal to commend it.

Or consider a society in which democratic processes work poorly, in the sense that they do not live up to democratic ideals, and also in which political majorities invade fundamental rights - say, freedom of religion and freedom of speech. Suppose that in this society, judges are trustworthy, in the sense that they can make democratic processes work better (say, by safeguarding the right to vote), and also that they can protect fundamental rights, as they really should be understood. In such a society, the argument for democracy-reinforcement, and for moral readings, would be quite strong.

We should now be able to see that none of these approaches is ruled out by the Constitution itself. Each can be implemented in a way that firmly respects the document's text and attempts to interpret it. The question is how to do so. If the founding document set out the rules for its own interpretation, judges would be bound by those rules (though any such rules would themselves need to be construed). But the Constitution sets out no such rules. For this reason, any approach to the document must be defended by reference to some account that is supplied by the interpreter.

The meaning of the Constitution must be made rather than found, not in the grand (and preposterous) sense that it is entirely up for grabs, but in the more mundane sense that it must be settled by an account of interpretation that it does not itself contain. The idea of interpretation is a capacious one, and a range of approaches fit within it. Among the reasonable alternatives, any particular approach to the Constitution must be defended on the ground that it makes the relevant constitutional order better rather than worse.

${ }^{83}$ See Antonin Scalia, The Rule of Law As A Law of Rules, 56 U Chi L Rev 1175 (1989). Note that minimalism is also an incomplete account of constitutional interpretation. We might agree that courts should favor small steps and incompletely theorized rulings; but within those constraints, in what directions shall they go? By itself, minimalism does not tell us. We could imagine Thayerian mimimalists, originalist minimalists, democracy-reinforcing minimalists, and many others.

${ }^{84}$ See David A. Strauss, The Living Constitution (2011). 